\title{
Urban restructuring in post-war contexts: the case of Sarajevo
}

\author{
JORDI MARTÍN-DÍAZ
}

\begin{abstract}
The transition from state-socialism to capitalism has not been the only process reshaping the urban landscapes in Central and Eastern Europe but some cities were affected by war destructions, like in the Caucus region or in the former Yugoslavia. The case study of Sarajevo, the capital of Bosnia and Herzegovina, is helpful to understand how the urban transformation is performed in post-war contexts, an arena neglected in the current literature on post-socialist cities. This paper aims at exploring the interplay between postsocialist urban restructuring and the peace-building process. It presents results of a series of fieldworks conducted in Sarajevo in 2010 and 2013. It is argued that in spite of the liberal policies implemented by the international community and the belated physical renewal, the transition from socialism to capitalism has been continuously undermined by the local power reconfiguration carried out during the war. The paper analyses the restructuring policies of the post-war period and its impact on the urban spatial structure. The first two sections focus on the urban restructuring processes of post-socialist cities also in post-war contexts, in which the nature of the internationally-led reconstruction and peace-building is analysed as differential processes. Finally, both processes are considered in the case of Sarajevo in relation to the transformation of its urban structure.
\end{abstract}

Keywords: post-socialist cities, post-war reconstruction, peace-building, ethnic territorialisation, Sarajevo

\section{Introduction}

Analysis of urban transformation in cities of Central and Eastern Europe has been high on the agenda in the last decade (e.g. Hamilton, I. 2005; Stanilov, K. 2007; Tsenkova, S. and Nedović-Budić, Z. 2006). It has covered, either comparatively or in case studies, a wide range of topics, like the changes in the urban structure (Hirt, S. 2006, 2008; Kovács, Z. 1994; SÝKORA, L. 2007), the

\footnotetext{
${ }^{1}$ Predoctoral Fellow, University of Barcelona, Department of Human Geography. Montalegre 6, Barcelona 08001, Spain. E-mail: jordi.martin@ub.edu
} 
forces producing the transition (Hamilton, I. 2005; Tosics, I. 2005), new forms of socio-spatial segregation (MARCINCZAK, S. et. al. 2013; SÝKORA, L. 2009), or more recently the emergence of gated communities as significant manifestation of such segregation (HirT, S. 2012; Kovícs, Z. 2014).

However, cities affected by war (like Grozny, Mostar or Sarajevo) have hardly attracted any attention in the literature about post-socialist cities. The few academic papers available have been produced either from a peace-building perspective (e.g. Moore, A. 2013) or with respect to the concept of divided cities (e.g. MAKAs, E. 2011). Therefore, this paper explores how post-socialist urban restructuring has been taking place in a post-war context and considers both peace-building and post-war reconstruction literature. It focuses on the case study city of Sarajevo, the capital of Bosnia and Herzegovina, which was the target of a three-and-a-half years siege that ended with the signature of the Dayton Peace Agreement (hereinafter DPA) in December 1995.

Beyond the wide and lingering media coverage of the siege, Sarajevo has not received any significant academic attention despite having experienced simultaneously the overlap of several transitions. None or few analyses have considered processes like its economic transition, the reconstruction of the city or the ethnic partitioning performed after the territorial organization set at the DPA. From the existing literature considering the city or its urban area during the war or post-war period Bollens, S.A. $(2006,2007)$ focused on the role of urban planning in the construction of multi-cultural societies in conditions of ethnic or nationalist disputes, while anthropologists have published the most significant number of works (ARMAKOLAs, I. 2007; Stefansson, A. 2007; MačEK, I. 2009; Markowitz, F. 2010).

In this regard, this paper presents preliminary results of a five-month fieldwork carried out in the city of Sarajevo in 2010 and 2013. Several methods have been applied in order to gather information on the urban transformation of the city, such as direct and fluctuant observation or semi-structured interviews with local and international actors. I argue that despite the liberal policies implemented by the international community and the belated physical renewal, the transition from socialism to capitalism has been continuously being undermined by the local power reconfiguration conducted during the war.

The paper is structured in four parts: the first the urban restructuring process of post-socialist cities in Central and Eastern Europe is introduced. Subsequently, the focus turns towards internationally-led reconstruction and peace-building processes, as differential features of post-socialist cities affected by war. The third section focuses on the reconstruction policies in Bosnia and Sarajevo. Finally, the economic restructuring agenda of the international community and its impact on the spatial urban structure is analysed. 


\section{Urban restructuring in Central and Eastern Europe}

The transition from state-socialism to capitalism resulted from the convergence of internal forces, i.e. efforts made either by local or foreign actors to dismantle the socialist structures, and external forces, which refer to processes not specifically connected to the transition (Hamilton, I. 2005; Tosics, I. 2005). Both forces have been progressively modifying the mechanisms producing the spatial forms for the market allocation, blurring the features of the socialist cities while acquiring the capitalist ones.

The analyses of the restructuring produced in post-socialist cities should not be considered as unique in the sense that it followed the global trend of post-Fordist de-industrialisation (Kovícs, Z. 1999). Thus, contemporary urban restructuring has been characterised by increasing internationalisation both in terms of capital and labour; changing power relations between public and private sector; industrial restructuring and an increasing social and economic polarisation or the emergence of post-modern urban landscapes characterised by new modes of urban culture and consumption (SÝKORA, L. 1994). These elements of the contemporary restructuring have progressively swept through the Central and Eastern European countries, having a major impact on the morphological features of their cities, which could be characterised during socialism by compactness, grand scale of public projects, absence of suburbanisation, visual monotony, and the oversupply of industrial areas and undersupply of commercial functions (SZELÉNYI, I. 1996).

The differences in the intensity of integration into the global flows as well as the importance of path-dependency have created some regional variations. Iván Tosics (2005) presented eight sub-types of development in post-socialist cities. He featured the Yugoslav cities, from which those from Slovenia were excluded, as follows:

Slow transition towards the capitalist city-model due to armed conflicts, mass refugee movements and destroyed urban centres. Very limited capital investments, firstly, there was a substantial local investment into illegal or unofficial property market. Relatively quick privatisation of public housing to sitting tenants at the beginning of the 1990s, but deferred restitution, privatisation of enterprises and other public assets due to the war disputes. Huge differentiation in incomes between the "formal" and the "informal" sectors, and very slow establishment of new type of public control over land market, planning and building process. The outcomes are densification and sprawl through unregulated development, which are running parallel with some elements of the "third world" type of city development" (TOSICS, I. 2005, p. 73).

In this context, while exploring how urban restructuring is performed in a post-war environment, this paper aims at addressing whether Sarajevo constitutes a typical Yugoslav post-socialist city. Before analysing in which 
way the changes in the urban spatial structure have occurred in the capital of Bosnia and Herzegovina, the nature of the reconstruction and peace-building processes is presented.

\section{Urban restructuring in post-war environments}

When the war ends the reconstruction and the deployment of peace-building missions to settle cease agreements become central for the future development of the war-torn societies. The reconstruction, defined at Cambridge dictionary as the building or creation of something that has been damaged or destroyed, implies a recovery of the pre-war status quo. Some practitioners and scholars are wary to use the concept reconstruction or rebuilding since pre-war political and societal structures are often at the core of violent conflicts. As a consequence, there is a difference between physical disasters and war-torn societies since in the former there is a restoration of institutional and physical infrastructures. As Krishna Kumar (1997) argues, reconstruction has three interrelated elements: the restoration, the structural reform - with the creation or dismantling of organisations, institutions and administrative structures - and the institution building, which involves improving the efficiency and affectivity of existing institutions (Kumar, K. 1997, p. 3).

A similar approach is used by the director of the Post-War Reconstruction and Development Unit (PRDU) at the University of York, Sultan BARAKAT (2010), who states that reconstruction is a "a range of holistic activities in an integrated process designed not only to reactivate economic and social development but also to create a peaceful environment that will prevent a relapse into violence" (BARAKAT, S. 2010, p. 11).

Since war-torn societies experience a massive economic downturn and might have previous structural shortages, the role of international aid is determining in this process. Among of the main organisations, the World Bank assists mainly economic recovery and normalisation, "post-conflict reconstruction supports the transition from conflict to peace in an affected country through the rebuilding of socioeconomic framework society (...) Reconstruction does not refer only to reconstruction of physical infrastructure. Nor does it necessarily signify rebuilding of the socioeconomic framework that existed in a country prior to the onset of the conflict (WB, 1998, p. 14). Contrary, the UN focuses on the importance of political reform, according to Boutros-Ghali definition of 1995 (BARAKAT, S. 2010).

Despite being etymologically instable in post-war contexts, there is consensus in defining reconstruction as a restructuring process addressing the political, institutional and social conditions which generated conflicts. The comprehensive renewal scope in the post-war reconstruction effort is visible in the strategy set to rebuild Bosnia. In this sense, the 5 billion USD Priority 
Reconstruction of Recovery Program (PRRP) coordinated by the World Bank included projects focusing on employment generation and demobilisation support, energy, landmine clearing, telecommunications, transport, education, health, housing, water and waste management, agriculture and industry. The PRRP had the challenge to restart economic transition to a market economy in a completely new social and political framework (WB, 1996).

Another significant feature differentiating the transition to capitalism in post-war environments is the development of complex peace-building missions. The aim of these internationally-led operations is eliminating the main causes of conflicts, to promote the security of individuals, social groups and the state, and to nurture features that create the conditions for a stable peace (Morphet, S. 2002). The rise of peace-building missions in the 1990s was a consequence of the volatility emerged after the collapse of the Cold-War geopolitical order. Actually, these missions were guided by the general notion that promoting liberalisation in countries affected by wars would create the conditions for a stable and lasting peace. As PARIs, R. (2004) concludes in his analysis of the fourteen peace-building missions developed between 1989 and 1999, this paradigm has not been a particularly effective model for establishing stable peace. It often created destabilising effects in war-shattered states while undermining the consolidation of peace or even renewed fighting.

In the Bosnian context, in which the urban restructuring of Sarajevo is framed, the peace-building mission had the very same goals, promoting quick political and economic liberalisation as the formula to create a sustainable peace. The mission was coordinated by the Office of the High Representative (OHR) set as the ad hoc body responsible of supervising and coordinating the civil aspects of the DPA. Its role evolved from supervision of the civil organisations and agencies to direct governance (CAPLAN, R. 2004). The empowerment of the High Representative was a consequence of the challenges posed by local forces in the implementation of the state and peace-building agendas. Hence the OHR directly intervened in most of the spheres of the civil implementation like economic reconstruction and development, resettlement of refugees and IDP's, civil administration, establishment of interim structures or the building of political institutions (DonaIs, T. 2005).

\section{Sarajevo: Geography of war and reconstruction}

Sarajevo's urban structure reflects the historically diverse urban growth, produced under the Ottoman rule, the Austro-Hungarian Monarchy, the Kingdom of Yugoslavia and the state-socialist period. The linear expansion towards the west along the valley eroded by the Miljacka river has resulted in little destruction of its urban heritage (CArreras, C. and Moreno, S. 2007). During socialist 
Yugoslavia the city experienced the most excessive urban development in its history with a rise of population from 99,000 inhabitants to 244,000 between 1948 and 1975 (Hamilton, F.E.I. 1979). In the census held before the war in 1991, the four central municipalities that constitute the City of Sarajevo and are considered in the current analysis - Stari Grad, Centar, Novo Sarajevo and Novi Grad - had altogether 361,000 inhabitants with a diverse ethnic background: 50 percent defined themselves as Muslims, 25 percent as Serbs, 13 percent as Yugoslavs, 6 percent as Croats and 4 percent as others ${ }^{2}$.

The transition from socialism to capitalism took a first major step in the former Yugoslavia when the Law on Social Capital was passed by the government of Ante Markovic, in 1989. However, the defeat of Communist Party by the nationalist parties in the first multi-party elections, celebrated in 1990 at the Republican level, stalemated the transition initiated by the Yugoslav Federal government. The situation in the city of Sarajevo during the economic and political crisis of late 1980s and early 90s was features of a weak government (DoniA, R. 2006).

In April 1992, after the recognition of the independence of Bosnia and Herzegovina, the war broke out in the former Yugoslav Republic, which triggered the lingering siege of Sarajevo between April 1992 and December 1995. The siege was part of the strategy of the Army of Republika Srpska to take some of the central areas of the city, causing 11,541 deaths and a wide destruction of its urban fabric. The DPA signed between the presidents of Bosnia and Herzegovina (Alija Izetbegović), Croatia (Franjo Tuđjman) and Serbia (Slobodan Milošević) settled the framework to end the hostilities and building a peaceful Bosnia and Herzegovina. Despite having been envisioned as a UN protectorate in previous peace negotiations, the city of Sarajevo was territorially split at the outskirts of the central municipalities between the two entities in which Bosnia was divided, the Federation of Bosnia and Herzegovina $(\mathrm{FBiH})$ and the Republika Srpska (RS).

After the siege the housing sector showed huge devastation through the war. Three out of the four municipalities of Sarajevo had a rate of building damages between 74 and 96 percent (IMG, 1999). The city, like the rest of the country, was heavily dependent on external aid in the process of reconstruction. The work to rebuild Sarajevo, in fact, did not start with the signature of DPA. By 1994, a team coordinated by William Eagleton, named as Special Coordinator for Sarajevo, headed seven action groups with a local counterpart to assess and set an action plan to restore essential public services in the city of Sarajevo. Local and international cooperation continued during the post-war reconstruction process, with municipalities having architects and engineers working closely with international donors. Donor Task Forces were established

${ }^{2}$ Current population and demographic data will be available from the first census since 1991 held in October 2013. 
to coordinate and lead the reconstruction of strategic sectors. The process of reconstruction did not imply a physical renewal since rebuilding of damaged and destroyed buildings had to be restored in the same way. This issue raised diverse visions, with the international donors more willing to use reconstruction to update materiality to new context and needs.

The physical reconstruction, considered as the most successful field of the international intervention, had both bilateral and multilateral aid programmes. The four-year PRRP was the main multi-donor programme for reconstruction. Its goal was to start the recovery process instead of restoring all infrastructures damaged, in order to generate local funds which should progressively replace the dependent aid economy, "it will be essential for the economy a growth momentum that can be sustained in the face of the inevitable future decline in external concessional assistance" (WB, 1998, p. viii). Notwithstanding, the lack of aid invested in the industrial sector, which made up 2.3 percent of the PRRP's expenditure (ICG, 1999) highlighted the restructuring nature of the programme since it neglected the main economic sector in the former Yugoslav Republic.

\section{The making of post-socialist Sarajevo}

The restructuring initiated by the IMF in late 1980s had hardly any results because of the nationalist escalation and finally it was halted by the dissolution of the country and the lingering armed conflict. In Bosnia, the political and economic liberalisation agenda was resumed well after the signature of the DPA, in a completely new social, political and territorial structure. In a framework of economic and aid dependence, local authorities were in control of the urban governance in the area of Sarajevo, and rapidly defined the strategies for the future development of the city. Therefore, in 1998 the "Sarajevo Canton Development Strategy until the Year 2015" was passed, with the main goals of making the city a European metropolis, a profitable business environment and a pleasant living environment (KS, 2000). These visions were developed in fourteen points, in which environmental considerations and the promotion of a profitable economy were central (MARTín-Díaz, J. et al. 2014). In the field of economic development the plan identified the introduction of an urban land market, or the strengthening of sectors like banking, financing or those industries acceptable in economic and environmental terms as generating new urban development in the city (KS, 2000).

In spite of the apparent commitment to economic and political transition by local powers, international actors were the sole force pushing for the transition to a market economy. Actually ethno-national parties continued pursuing wartime goals by political means (Leroux-MArTin, P. 2014), with the ethnic territorialisation or the accumulation by dispossession still being 
performed. As a consequence, the international community became a very central actor in the governance of the country and the city. In order to solve the stalemate in the reforms set at the DPA, the High Representative was granted with executive and legislative power in December 1997.

The complexity of this process required overcoming the obstructionism of localised power structured by building of new institutions (DonAIs, T. 2002). After the empowerment, the lingering legislative effort aimed at fostering the liberal and state-building agenda was started through the privatisation of public assets, the fiscal reform or the attraction of foreign capital (Table 1).

Indeed, the power granted to the OHR found in the resistance of the ethno-parties a continuous force undermining the transition from socialism to capitalism. The poor performance of the economy, with a low capacity to attract foreign capital despite the international intervention, shows the limits to build a market economy in a context of political instability and lack of local cooperation. In this sense, the Foreign Direct Investment (FDI) exceeded the one billion Euros threshold only in 2007, despite the several economic packages enacted by the OHR, while FDI has always been much below the remittances amount (WB, 2011).

Table 1. Liberalisation policies in Bosnia and Herzegovina in the post-war period

\begin{tabular}{|c|c|c|}
\hline Year & Law & Category \\
\hline 1997 & $\begin{array}{l}\text { FBiH House of Peoples adopts laws on the } \\
\text { Privatisation of enterprises, sale of apartments } \\
\text { with tenants' rights, and citizens requests in } \\
\text { the Privatisation process }\end{array}$ & Privatisation of public assets \\
\hline 1998 & $\begin{array}{l}\text { OHR's Decision imposing the Framework on } \\
\text { Privatisation of Enterprises and Banks in BiH }\end{array}$ & Privatisation of public assets \\
\hline 1998 & $\begin{array}{l}\text { OHR's Decision imposing the Draft Law on the } \\
\text { policy of Foreign Direct Investment in } \mathrm{BiH}\end{array}$ & Economic liberalisation \\
\hline 1998 & $\begin{array}{l}\text { OHR's Decision establishing the Privatisation } \\
\text { Monitoring Commission }\end{array}$ & Privatisation of public assets \\
\hline 2000 & $\begin{array}{l}\text { OHR's Decision amending the Framework } \\
\text { Law on Privatisation of Enterprises and Banks } \\
\text { by introducing a clause protecting investors }\end{array}$ & Privatisation of public assets \\
\hline 2001 & $\begin{array}{l}\text { OHR's Decision enacting the Law on Land } \\
\text { Registry in FBiH and RS }\end{array}$ & Economic liberalisation \\
\hline 2003 & $\begin{array}{l}\text { OHR's Decision Establishing the Indirect Tax } \\
\text { Policy Commission }\end{array}$ & Fiscal reform \\
\hline 2003 & $\begin{array}{l}\text { OHR's Decision Enacting the Law on } \\
\text { Construction Land of the FBiH and RS }\end{array}$ & $\begin{array}{l}\text { Creation real-estate market / } \\
\text { Privatisation of public assets }\end{array}$ \\
\hline 2004 & $\begin{array}{l}\text { OHR's Decision Enacting the Law on } \\
\text { Amendments to the Law on the Indirect } \\
\text { Taxation System in } \mathrm{BiH}\end{array}$ & Fiscal reform \\
\hline
\end{tabular}

Source: Information from the OHR database. 
Liberalisation policies in the economy were implemented without considering the local circumstances, causing counterproductive outcomes like those produced in the quick privatisation process of public assets. In this sense the privatisation before institutionalisation (PARIS, R. 2004) became a tool for the local elites to consolidate their position (Donais, T. 2002, 2005). As Michael PUGH (2005) pointed out in this controversial process, "the clientelist and neoliberal mechanisms for managing investment, shares, and profits are dissimilar. But the normative assumptions of the external actors and the interests of domestic elites coincide in extracting profit from public goods and in fostering opportunities from privatization and discrimination against social ownership" (Pugh, M. 2005, p. 467).

The land management, in contrast, is an eloquent example of how liberalisation can be adapted to the implementation of the peace-building agenda. Hence, the attempts to create a real-estate market were halted after the decision by the OHR to restrict land allocation in 1999. The purpose was preventing land allocations aimed at consolidating ethnic territorialisation (Thuatail, G. and Dahlman, C. 2006), which undermined the policies pursuing the rebuilding of a multi-ethnic Bosnia and Herzegovina. A central issue in the return of refugees and internally displaced persons (IDP's) was the housing repossession, which had been prevented by the nationalist parties in order to preserve the ethnic reconfiguration achieved during the war. As a consequence of the eviction of those who had been settled temporarily in Sarajevo, the process of suburbanisation at the outskirts of the city or on the slopes, which existed already during socialist times, was restarted again in the late 1990s (Martín-Díaz, J. et al. 2014).

After the four-year period of land management, the Law on Construction Land enacted by the OHR in May 2003 allowed the privatisation of land (OHR, 2003), starting the major wave of real estate development in the city. Most of the new urban projects built since then have been developed in the central areas of the narrow valley in which the city of Sarajevo is stretching. They are especially concentrated in the municipalities of Novi Grad and Novo Sarajevo, developed during the socialist period.

In order to analyse the features of the post-socialist functional transformation 109 new urban projects developed in the post-war period were identified during the field-work, and they were grouped in eight categories ${ }^{3}$ (Figure 1).

Office buildings represent 39 percent of new developments which is followed by commercial projects $(21 \%)$, either supermarkets or shopping

\footnotetext{
${ }^{3}$ The elaboration of the data base on new urban projects was produced during fieldworks through several techniques, such as direct observations and semi-structured interviews. The selected projects are newly developed or redeveloped, with functional change or aesthetical upgrading (e.g. BBI Center, Photo 1). New single family dwellings were not considered. The qualitative information obtained was confirmed through historical pictures from the siege (Prstojević, M. 1994).
} 


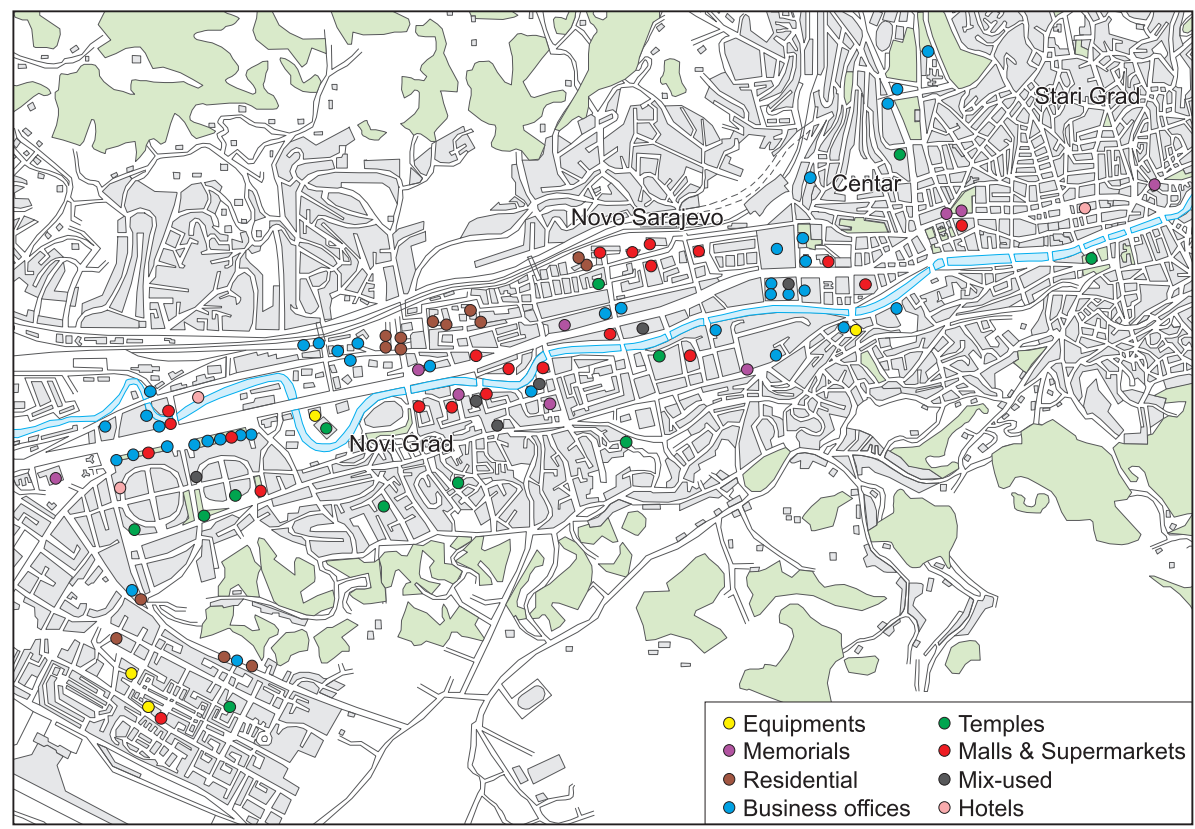

Fig. 1. Location of new urban projects in post-war Sarajevo

centres (Photo 2). The third category is formed by multi-family housing (14\%) developed in the last few years, mainly by private investors. Considering mix-used developments, like the Bosmal City Centar (Photo 3) or the Importanne Centar, office and commercial projects reach three quarters of new post-war projects, highlighting the tertiarisation of the economy and the development of new modes of consumption. Regarding the symbolic projects, temples and memorials count together 15 percent. Even if symbolic projects were not quantitatively significant, mosques funded by countries like Saudi Arabia, Turkey or Malaysia, have been widespread in the city. With exogenous architecture, like the mosques built with two minarets, these projects are rather controversial but they well reflect the re-formulation of the city's identity.

Most of the new projects have been developed by private investors only a few services, like a couple of schools or the so-called Olympic Pool, have been funded by some public money. The main developers, thus, are private (both local and international) and projects are often built without permit. Regarding international investments, capitals from Austria and Islamic countries are prevalent. Investors from Malaysia or Saudi Arabia have been central in the development of the main new projects in the city, like the Bosmal City Centar or the Sarajevo City Centar, that were recently opened. 


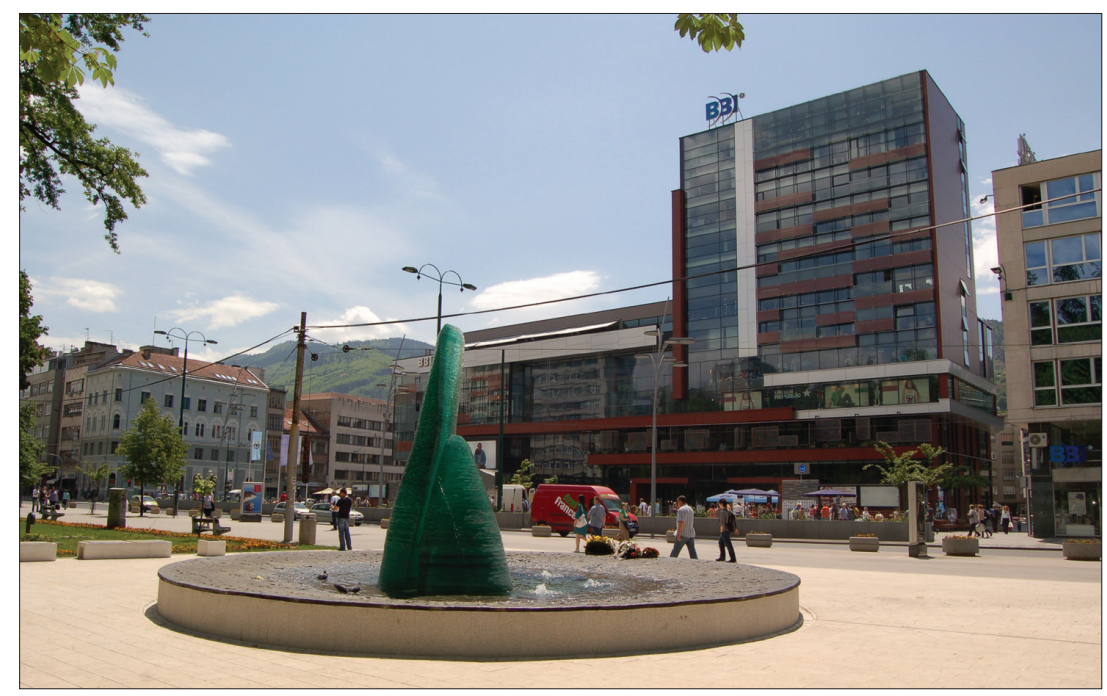

Photo 1. The new BBI Center in Sarajevo
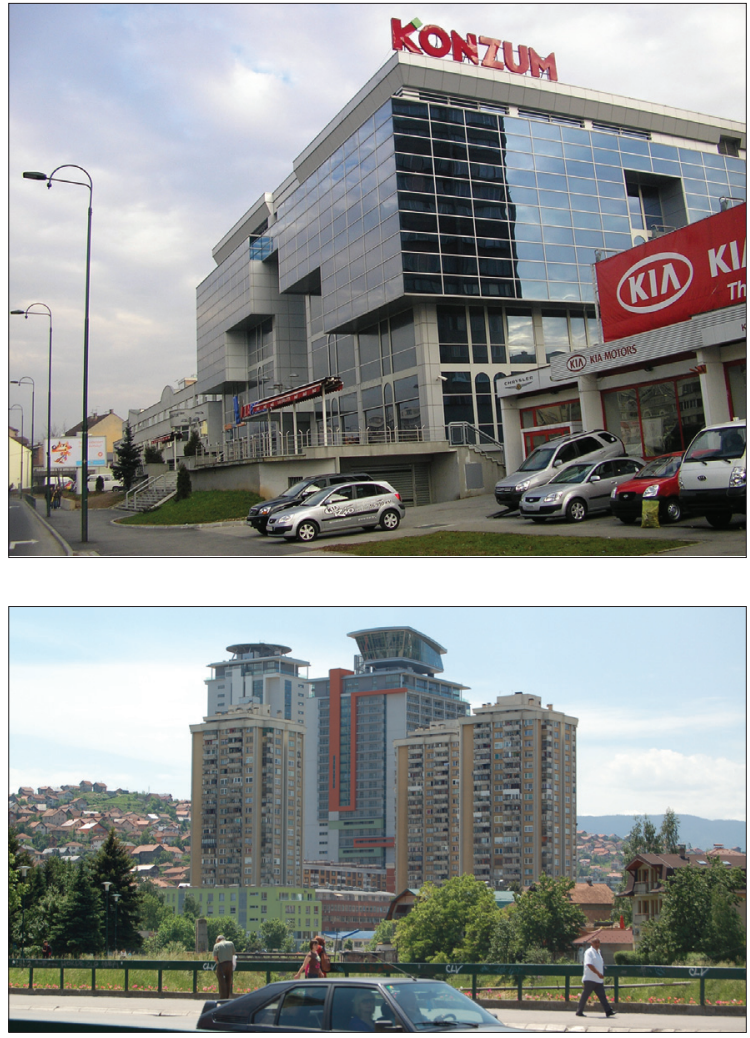

Photo 2. New supermarkets in central Sarajevo

Photo 3. Bosmal City Centar in Sarajevo (Photos taken by the author) 
Considering the pace of transformation, information on sixty-six new urban projects was available at the data base of the Sarajevo Construction (SC, 2014). Most of them have been built since 2005, which highlights the speed of growth of new urban projects resulting from liberalisation policies. These new urban projects have substantially transformed the urban structure and landscape of the four central municipalities constituting the city of Sarajevo, leading to the densification of the central areas and an increasing functional diversity so much characteristic for other post-socialist cities like Sofia (HIRT, S. 2006), Prague (SÝKora, L. 2007), Budapest (Kovács, Z. 1994) or Belgrade (HirT, S. 2008). These new post-modern architectures have also brought about a significant aesthetic transformation, implying globalisation and rising diversity in the predominantly traditional neighbourhoods.

\section{Conclusions}

This paper investigated how the post-war reconstruction and peace-building missions deployed by the international community to rebuild war-torn societies generate restructuring processes following liberal principles. Although cities affected by wars experience massive urban transformations beyond the physical destruction of their urban fabric, the liberal policies pursued by international organizations hardly consider local contexts. The complexity of the Bosnian case, in which the ethno-national parties continued pursuing war goals by political means caused the embedding of the international community in the governance of the country.

The development of Sarajevo has been featured by succession of crisis since the late 1980s, in which the three-and-a-half year siege destroyed large part of the urban structure at the beginning of the 1990s. Considering changes in the urban structure, the transformation of the city can be divided into two periods since the war ended in December 1995. The first period focused on the main post-war challenges. The physical reconstruction was a priority of local and international actors. Concurrently, some symbolic projects were built and the management of the return of IDP's and refugees resumed forms of suburbanisation that had existed in socialist times.

The second period, from 2003 onwards, was the result of the restructuring policies pursued by the international actors as the way to replace the aid dependent economy for a self-sustainable economy. The creation of a realestate market, belated by the strategy of the international community to avoid housing developments that fostered ethnic territorialisation, finally triggered a new wave of urban renewal. The emergence of private developers as key urban actors and the functional and aesthetical change characteristic also for other post-socialist cities have been the main features in Sarajevo. 
Therefore, the transformation described by Iván Tosics in the exYugoslav cities (2005) - with slow transition towards the capitalist city-model, the limited capital investments at the beginning, the substantial investment of local people into illegal or unofficial property, or a parallel process of densification and sprawl - has been largely identified in the urban development of the city since the end of the war.

Sarajevo is a post-socialist city because of the political economy operating during state-socialism, and shaping the urban development of the city, since the late 1980s. The city has clearly acquired capitalist features as it was highlighted in the analysis about the changes in its urban spatial structure. However, Sarajevo constitutes a particular case in the literature of post-socialist cities. The large transformation caused during the war has been undermining the effects of the policies adopted by international actors. There are evidences, like the poor attraction of FDI, pointing towards the current hybrid structure, the political instability and the incompleteness of the transition into a capitalist system. Thus, further analyses are required for the better understanding of the ongoing transition, in issues such as the dialectics between local and international actors, or the relationship between new urban projects and the socio-ethnic and cultural transformations that started during the siege and are continuously reproduced by local politics and the split between the cities of Sarajevo and East Sarajevo.

Acknowledgements: This work has been financially supported by the Spanish Ministry of Education. The author would like to thank Zoltán Kovács for his invitation to participate in this special issue about post-socialist cities as well as in the EUGEO 2013 Congress in Rome.

\section{REFERENCES}

Armakolas, I. 2007. Sarajevo No More? Identity and the Experience of Place among Bosnian Serb Sarajevans in RS. In The New Bosnian Mosaic: Identities, Memories and Moral Claims in a Post-War Society. Eds. Bougarel, X. et al. Aldershot, Ashgate. 79-99.

Barakat, S. 2010. After the Conflict: Reconstructions and Redevelopment in the Aftermath of War. London, I. B. Tauris. $344 \mathrm{p}$.

Bollens, S.A. 2006. Urban planning and peace building. Progress in Planning 66. 67-139.

Bollens, S.A. 2007. Cities, Nationalism and Democratization. London \& New York, Routledge. $283 \mathrm{p}$.

CAPlan, R. 2004. International Authority and State Building: The Case of Bosnia and Herzegovina. Global Governance 10. (1): 53-65.

Carreras, C. and Moreno, S. 2007. Los procesos de modernización en Sarajevo: la incierta dirección de la flecha del tiempo. Anales de Geografía de la Universidad Complutense de Madrid 27. 29-44.

Donais, T. 2002. The Politics of Privatization in Post-Dayton Bosnia. Southeast European Politics 3. (1): 3-19. 
Donais, T. 2005. The Political Economy of Peacebuilding in Post-Dayton Bosnia. New York, Routledge. 207 p.

Donia, R. 2006. Sarajevo: A Biography. London, C. Hurst \& Co., 435 p.

Hamilton, F.E.I. 1979. Urbanization in Socialist Eastern Europe. The macro-environment of internal city structure. In The socialist city: spatial structure and urban policy. Eds. French, R.A. and Hamilton, F.E.I., New York, John Wiley \& Sons. 167-194.

Hamilton, F.E.I. 2005. The external forces: Towards globalization and European. In Transformation of cities in Central and Eastern Europe: Towards globalization. Eds. Hamilton, F.E.I. et al. Tokyo, United Nations University Press. 79-115.

Hirt, S. 2006. Post-Socialist Urban Forms: Notes From Sofia. Urban Geography 27. (5): 464-488.

Hirt, S. 2008. Landscapes of Post-modernity: Changes in the Built Fabric of Belgrade and Sofia Since the End of Socialism. Urban Geography 29. (8): 785-810.

Hirt, S. 2012. Iron Curtains: Gates, Suburbs and Privatization of Space in the Post-socialist City. Chichester, Wiley-Blackwell. 252 p.

ICG 1999. Why will no one invest in Bosnia and Herzegovina? International Crisis Group, Balkans Report 64.24 p.

IMG 1999. War damaged residential building residential buildings and status on repair. Sarajevo, International Management Group. 12 p.

Kovács, Z. 1994. A City at the Crossroads: Social and Economic Transformation in Budapest. Urban Studies 31. (7): 1081-1096.

Kovács, Z. 1999. Cities from state socialism to global capitalism: an introduction. GeoJournal 49. (1): 1-6.

Kovács, Z. 2014. New post-socialist urban landscapes: The emergence of gated communities in East Central Europe. Cities 36. 179-181.

KS 2000. Sarajevo Canton development strategy until the year 2015. Kanton Sarajevo, Sarajevo, $93 \mathrm{p}$.

Kumar, K. 1997. Rebuilding Societies After Civil War: Critical Roles for International Assistance. Lynne Rienner. 256 p.

Leroux-Martin, P. 2013. Diplomatic Counterinsurgency: Lessons from Bosnia and Herzegovina. Cambridge, Cambridge University Press. 323 p.

Мас̌Eк, I. 2009. Sarajevo Under Siege: Anthropology in Wartime. Philadelphia, University of Pennsylvania Press, $272 \mathrm{p}$.

MAKAs, E. 2011. Mostar's central zone: battles over shared space in a divided city. Urban Conflicts: Ethno-Nationalist Divisions. A paper for State ad Cities Conference, Belfast, Queen's University.

Marcinczak, S., Gentile, M. and StepniaK, M. 2013. Paradoxes of (post)socialist segregation: Metropolitan socio-spatial divisions under socialism and after in Poland. Urban Geography 34. (3): 327-352.

Markowitz, F. 2010. Sarajevo A Bosnian Kaledoscoip. Chicago, University of Illinois Press, 240 p.

Martin-Díaz, J., Nofre, J. and Olivia, M. 2014. Towards an unsustainable urban development in post-war Sarajevo. (Forthcoming)

Moore, A. 2013. Peacebuilding in practice. Local Experience in Two Bosnian Towns. New York, Cornell University Press. 240 p.

Morphet, S. 2002. Current International Civil Administration: The Need for Political Legitimacy. International Peacebuilding 9. (2): 140-162.

OHR 2003. Decision Enacting the Law on Construction Land of the Federation of Bosnia and Herzegovina. Sarajevo, Office of the High Representative, www.ohr.int, Accessed 30 May 2014. 
PARIS, R. 2004. At War's End: Building Peace after Civil Conflict. Cambridge, Cambridge University Press. 304 p.

Prstojević, M. 1994. Sarajevo, ranjeni grad. Ljubljiana, PP Ideja. 320 p.

Pugh, M. 2002. Post-war political economy in Bosnia and Herzegovina: The spoils of peace. Global Governance 8. 467-482.

SC 2014. Sarajevo Construction. www.sa-c.net Accessed 29 May 2014.

Stanilov, K. 2007. The Post-Socialist City. Urban Form and Space Transformations in Central and Eastern Europe after Socialism. Netherlands, Springer. 496 p.

Stefansson, A. 2007. Urban Exile: Locals, Newcomers and the Cultural Transformation of Sarajevo. In The New Bosnian Mosaic: Identities, Memories and Moral Claims in a PostWar Society. Eds. Bougarel, X. et al., Burlington, Ashgate. 59-79.

SÝkoRA, L. 1994 Local Urban Restructuring as a Mirror of Globalisation Processes: Prague in the 1990s. Urban Studies 31. (7): 1149-1166.

SÝкоRA, L. 2007. Office development and post-communist city formation: The case of Prague. In The Post-Socialist City. Urban Form and Space Transformations in Central and Eastern Europe after Socialism. Ed. STANILov, K., Netherlands, Springer. 117-146.

SýKоRA, L. 2009. New socio-spatial formations: places of residential segregation and separation in Czechia. Tijdschrift voor Economische en Sociale Geografie 100. (4): 417-435.

SzelénYI, I. 1996. Cities under Socialism - and After. In Cities after Socialism. Eds. Andrusz, G. et al., Oxford, Blackwell Publishers Inc., 286-317.

Tosics, I. 2005. City development in Central and Eastern Europe since 1990: The impacts of internal forces. In Transformation of cities in Central and Eastern Europe: Towards globalization. Eds. Hamilton, F.E.I. et al., Tokyo, United Nations University Press. 44-78.

Tsenkova, S. and Nedović-Budić, Z. 2006. The urban mosaic of post-socialist Europe: space, institutions and policy. Heidelberg, Physica-Verlag Heidelberg. 390 p.

Tuathail, G. and Dahlman, C. 2006. The "West Bank of the Drina": Land Allocation and Ethnic Engineering in Republika Srpska. Transactions Institute of British Geographers 31. (3): 304-322.

WB 1996. Bosnia and Herzegovina Towards Economic Recovery. Washington DC, World Bank. $68 \mathrm{p}$.

WB 1998. Post-conflict reconstruction: the role of the World Bank. Washington DC, World Bank $70 \mathrm{p}$.

WB 2011. The Migration and Remittances factbook. www.worldbank.org, Accessed 30 May 2014. 


\title{
Hungary in Maps
}

\author{
Edited by \\ Károly Kocsis and Ferenc Schweitzer
}

\section{Geographical Research Institute Hungarian Academy of Sciences Budapest, 2009. 212 p.}

'Hungary in Maps' is the latest volume in a series of atlases published by the Geographical Research Institute of the Hungarian Academy of Sciences. A unique publication, it combines the best features of the books and atlases that have been published in Hungary during the last decades. This work provides a clear, masterly and comprehensive overview of present-day Hungary by a distinguished team of contributors, presenting the results of research in the fields of geography, demography, economics, history, geophysics, geology, hydrology, meteorology, pedology and other earth sciences. The 172 lavish, full-colour maps and diagrams, along with 52 tables are complemented by clear, authoritative explanatory notes, revealing a fresh perspective on the anatomy of modern day Hungary. Although the emphasis is largely placed on contemporary Hungary, important sections are devoted to the historical development of the natural and human environment as well.

In its concentration and focus, this atlas was intended to act as Hungary's 'business card', as the country's résumé, to serve as an information resource for the sophisticated general reader and to inform the international scientific community about the foremost challenges facing Hungary today, both in a European context and on a global scale. Examples of such intriguing topics are: stability and change in the ethnic and state territory, natural hazards, earthquakes, urgent flood control and water management tasks, land degradation, the state of nature conservation, international environmental conflicts, the general population decline, ageing, the increase in unemployment, the Roma population at home and the situation of Hungarian minorities abroad, new trends in urban development, controversial economic and social consequences as a result of the transition to a market economy, pri-

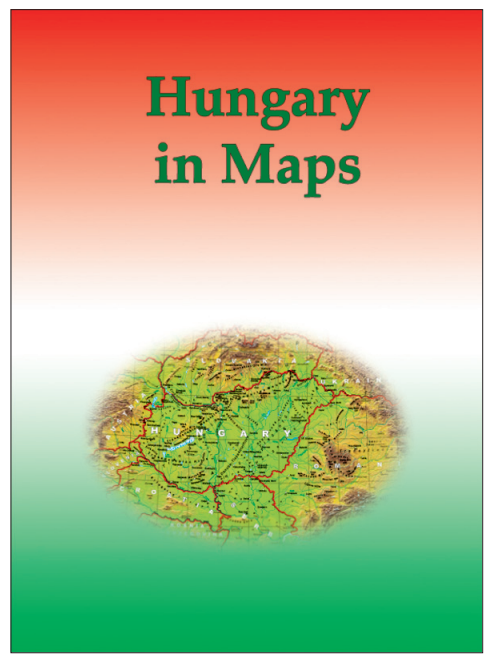
vatisation, the massive influx of foreign direct investment, perspectives on the exploitation of mineral resources, problems in the energy supply and electricity generation, increasing spatial concentration focused on Budapest in the field of services (e.g. in banking, retail, transport and telecommunications networks), and finally the shaping of an internationally competitive tourism industry, thus making Hungary more attractive to visit.

This project serves as a preliminary study for the new, 3rd edition of the National Atlas of Hungary, that is to be co-ordinated by the Geographical Research Institute of the Hungarian Academy of Sciences.

Price: EUR 20.00

Order: Geographical Institute RCAES HAS Library

H-1112 Budapest, Budaörsi út 45.

E-mail: magyar.arpad@csfk.mta.hu 